\title{
Elemental analysis as an important tool for fuels and biofuels quality control
}

Article presents normalized analytical methods for determination of elements in fuels and biofuels with emphasis on inductively coupled plasma emission spectrometry (ICP-OES) and their advantages and disadvantages. Analytical procedure applied for determination of 20 elements ( $\mathrm{Al}, \mathrm{B}, \mathrm{Ba}, \mathrm{Ca}, \mathrm{Cr}, \mathrm{Cu}, \mathrm{Fe}, \mathrm{K}, \mathrm{Mg}, \mathrm{Mn}, \mathrm{Mo}, \mathrm{Na}, \mathrm{Ni}, \mathrm{P}, \mathrm{Pb}, \mathrm{Si}, \mathrm{Sn}, \mathrm{Ti}, \mathrm{V}$ and $\mathrm{Zn}$ ) is described with elements of validation. Broad range of elemental analysis results of fuels $(B O, B 7$ and B10) and pure FAME samples are described. Typical contents of selected elements are presented which allows discussion on the domestic fuel quality in regard to non-standardized parameters and their potential effect on combustion engines performance.

Key words: fuels, biofuels, FAME, elemental composition, ICP-OES

\section{Introduction}

Analysis of liquid petroleum products characteristics is a challenge for every chemist due to variety of these products (petroleum, diesel fuel, biofuels, engine oils, gear oils, hydraulic oils, coolants etc.). Conclusion regarding these products quality are usually based on numerous laboratory analyses.

In order to determine diesel fuel quality analyses are required such as cetane number and cetane index, distillation characteristics, density, viscosity, fatty acid methyl esters (FAME) content, water content, polycyclic aromatic hydrocarbons content, flash point, carbon residue, total contamination, copper strip corrosion, oxidation stability, lubricity and climate dependent cold filter plugging point and cloud point. Within the analyzed range of properties are also concentration of manganese and sulfur which content is checked and verified against EN 590 standard's requirements, as the only elements in diesel fuel which concentration need to be indicated directly [1]. In case of petrol concentration of three elements need to be verified against EN 228 [2] requirements namely: lead, sulfur and manganese. Other parameters which has to be checked to control fuel quality are: distillation characteristics, vapour pressure, density, research and motor octane number, oxidation stability, existent gum content, copper strip corrosion, aromatics and olefins hydrocarbons content, oxygen and oxygenates content and benzene content. More detailed elements analysis is required in case of fatty acids methyl esters [3], in which sulfur, phosphorus, sodium, potassium, calcium and magnesium concentrations need to be checked in order to verify this component quality. In fact, normative requirements regarding these elements concentration are only ones allowing estimation of some guideline values for discussion on elemental concentration in regular fuels. These should be free from any adulterant or contaminant that may render the fuel unacceptable for use in engine vehicles as it is described in both EN 228 and EN 590 standards [1, 2].

Determination of concentration of wide variety of elements requires proper sample preparation before measurement, as well as application of suitable measurement technique which would allow reaching very low limits of determination (LOD) leading to precise and repeatable results despite the demanding organic matrix.
This paper discusses trace elements analysis in liquid fuels: diesel and biodiesel fuels. In BOSMAL Automotive Research and Development Institute Ltd fuel quality check includes routine determination of 20 elements (Al, B, Ba, $\mathrm{Ca}, \mathrm{Cr}, \mathrm{Cu}, \mathrm{Fe}, \mathrm{K}, \mathrm{Mg}, \mathrm{Mn}, \mathrm{Mo}, \mathrm{Na}, \mathrm{Ni}, \mathrm{P}, \mathrm{Pb}, \mathrm{Si}, \mathrm{Sn}, \mathrm{Ti}, \mathrm{V}$ and $\mathrm{Zn}$ ) concentration in case of diesel and biodiesel. In case of fuels without biocomponents concentration of these elements are usually below $1 \mathrm{mg} / \mathrm{kg}$.

\section{Elemental analysis of fuels and biofuels}

\subsection{Legal requirements}

As it was mentioned above, only limited number of elements is an object of normative regulation. In case of sulfur and manganese 10 and $2 \mathrm{mg} / \mathrm{kg}$, respectively, is upper allowed concentration in petrol and diesel, and additionaly in case of petrol lead content is limited to max $5 \mathrm{mg} / \mathrm{kg}$. In case of FAME used as a $100 \%$ biofuel or blending component in diesel fuel, six elements content is limited namely: sulfur ( $\max 10 \mathrm{mg} / \mathrm{kg}$ ), phosphorous ( $\max$ $4 \mathrm{mg} / \mathrm{kg}$ ), summary content of sodium and potassium content limited to max $5 \mathrm{mg} / \mathrm{kg}$, exactly the same as summary content of calcium and magnesium. On the other hand sodium, zinc and silicon content above $2 \mathrm{mg} / \mathrm{kg}$ may have negative impact on injectors performance of modern diesel engines, furthermore increased concentration of some elements may result in engine components corrosion and formation of deposits at elevated temperatures [4, 5]. Taking into account these negative aspects of trace elements presence, their concentrations in fuels should be monitored, especially during the demanding process of engine testing.

\subsection{Methods of trace elements determination}

Trace elements concentration is usually measured by spectroscopic methods, mainly inductively coupled plasma optical/atomic emission spectrometry (ICP-OES, ICP-AES) and wavelength or energy dispersive X-ray fluorescence (WD-XRF, ED-XRF). Comparison of standardized methods with description of sample preparation, measurement parameters for different petroleum products and concentration ranges is presented in Table 1 and 2. 
Table 1. List of standardized ICP-OES/AES measurement methods for determination of elements in fuels, biofuels and biocomponents

\begin{tabular}{|c|c|c|c|c|}
\hline $\begin{array}{l}\text { Sample } \\
\text { type }\end{array}$ & $\begin{array}{c}\text { Sample } \\
\text { preparation }\end{array}$ & $\begin{array}{l}\text { Analyzed } \\
\text { elements }\end{array}$ & $\begin{array}{c}\text { Measurement } \\
\text { range } \\
{[\mathrm{mg} / \mathrm{kg}]^{*}}\end{array}$ & Bibl. \\
\hline \multicolumn{5}{|c|}{ Inductively coupled plasma optical emission spectrometry ICP-OES } \\
\hline Ethanol & $\begin{array}{l}\text { Direct meas- } \\
\text { urement }\end{array}$ & $\begin{array}{c}\mathrm{P} \\
\mathrm{Cu} \\
\mathrm{S}\end{array}$ & $\begin{array}{c}0.13-1.90 \\
0.050-0.300 \\
2-15\end{array}$ & [6] \\
\hline FAME & $\begin{array}{c}\text { Dilution with } \\
\text { naphtha (mas. } \\
1: 2 \text { ) }\end{array}$ & $\begin{array}{c}\mathrm{Ca}, \mathrm{K}, \mathrm{Mg}, \\
\mathrm{Na}\end{array}$ & $1-10$ & [7] \\
\hline $\begin{array}{l}\text { Unleaded } \\
\text { petrol }\end{array}$ & $\begin{array}{l}\text { Dilution 20x } \\
\text { with naphtha }\end{array}$ & Mn & $2-8[\mathrm{mg} / \mathrm{l}]$ & [8] \\
\hline FAME & $\begin{array}{c}\text { Dilution } 4 x \\
\text { with naphtha, } \\
\text { IS: Co, Sc, Y }\end{array}$ & $\mathrm{P}$ & $2.5-8.0$ & [9] \\
\hline $\begin{array}{l}\text { Diesel (up } \\
\text { to } 30 \% \text { vol. } \\
\text { of FAME) }\end{array}$ & $\begin{array}{c}\text { Dilution with } \\
\text { kerosene } \\
\text { (mas. 1:1) IS: } \\
\text { Co, Sc,Y }\end{array}$ & $\begin{array}{c}\mathrm{Na} \\
\mathrm{K}, \mathrm{P} \\
\mathrm{Ca} \\
\mathrm{Cu}, \mathrm{Zn}\end{array}$ & $\begin{array}{l}1.2-2.5 \\
0.9-2.5 \\
0.3-2.5 \\
0.2-2.5\end{array}$ & {$[10]$} \\
\hline $\begin{array}{l}\text { Liquid } \\
\text { petroleum } \\
\text { products: } \\
\text { fuels, } \\
\text { crude } \\
\text { petroleum } \\
\text { fuel } \\
\end{array}$ & $\begin{array}{c}\text { Dilution } 10 x \\
\text { with organic } \\
\text { solvent } \\
\text { (naphtha, } \\
\text { xylene) IS: } \\
\text { Co, Sc, Y }\end{array}$ & $\begin{array}{l}\mathrm{Ni} \\
\mathrm{V}\end{array}$ & $\begin{array}{c}4-55 \\
4-150\end{array}$ & [11] \\
\hline FAME & $\begin{array}{c}\text { Dilution 10x } \\
\text { min. with } \\
\text { xylene or } \\
\text { other organic } \\
\text { solvent } \\
\end{array}$ & $\mathrm{P}$ & $4-20$ & {$[12]$} \\
\hline $\begin{array}{l}\text { Diesel (up } \\
\text { to } 10 \% \text { vol. } \\
\text { of FAME) }\end{array}$ & $\begin{array}{c}\text { Dilution with } \\
\text { kerosene (1:1) } \\
\text { IS: Co, Sc, Y }\end{array}$ & $\mathrm{Fe}, \mathrm{Mn}$ & $0.5-7.0$ & {$[13]$} \\
\hline \multicolumn{5}{|c|}{ Inductively coupled plasma atomic emission spectrometry ICP-AES } \\
\hline $\begin{array}{l}\text { Fuels } \\
\text { (boiling } \\
\text { range } 150 \\
\div 390^{\circ} \mathrm{C}\end{array}$ & $\begin{array}{l}\text { Direct meas- } \\
\text { urement }\end{array}$ & $\begin{array}{c}\mathrm{Ag}, \mathrm{Al}, \mathrm{Ba}, \\
\mathrm{Ca}, \mathrm{Co}, \mathrm{Cr}, \\
\mathrm{Cu}, \mathrm{Fe}, \mathrm{K}, \\
\mathrm{Li}, \mathrm{Mg}, \\
\mathrm{Mn}, \mathrm{Mo}, \\
\mathrm{Na}, \mathrm{Ni}, \mathrm{P}, \\
\mathrm{Pb}, \mathrm{Pd}, \mathrm{Pt} \\
\mathrm{Si}, \mathrm{Sr}, \mathrm{Sn}, \\
\mathrm{Ti}, \mathrm{V}, \mathrm{Zn}\end{array}$ & $0.1-2.0$ & {$[4]$} \\
\hline $\begin{array}{l}\text { Liquid } \\
\text { fuels: } \\
\text { naphtha, } \\
\text { diesel and } \\
\text { similar }\end{array}$ & $\begin{array}{l}\text { Direct meas- } \\
\text { urement or } \\
\text { dilution with } \\
\text { organic } \\
\text { solvent }\end{array}$ & $\begin{array}{c}\mathrm{Ba}, \mathrm{B}, \mathrm{Cr}, \\
\mathrm{Ag}, \mathrm{Al}, \mathrm{Cu}, \\
\mathrm{Ca}, \mathrm{Fe}, \mathrm{K}, \\
\mathrm{Mg}, \mathrm{Mn}, \\
\mathrm{Mo}, \mathrm{Na}, \\
\mathrm{Ni}, \mathrm{P}, \mathrm{Pb}, \\
\mathrm{S}, \mathrm{Si}, \mathrm{Sn}, \\
\mathrm{Ti}, \mathrm{V}, \mathrm{Zn}\end{array}$ & $\begin{array}{c}0.1-5.0 \text { (for } \\
\text { direct } \\
\text { measurements) }\end{array}$ & {$[14]$} \\
\hline $\begin{array}{l}\text { Fresh oils } \\
\text { and fuels }\end{array}$ & $\begin{array}{c}\text { Method } \mathrm{A}- \\
\text { dilution } 10 \mathrm{x} \\
\text { mas. with } \\
\text { organic } \\
\text { solvent } \\
\text { Method } \mathrm{B}- \\
\text { mineralization } \\
\text { with } \mathrm{H}_{2} \mathrm{SO}_{4} \\
\text { and } \\
\text { combustion in } \\
525^{\circ} \mathrm{C}, \\
\text { residue } \\
\text { dissolved in } \\
\mathrm{HNO}_{3}\end{array}$ & $\begin{array}{l}\mathrm{Fe} \\
\mathrm{Ni} \\
\mathrm{V}\end{array}$ & $\begin{array}{c}1-10 \\
10-100 \\
50-500\end{array}$ & {$[15]$} \\
\hline
\end{tabular}

* - other units indicated below, IS - Internal Standard
Table 2. List of standardized other measurement methods for determination of elements in fuels, biofuels and biocomponents

\begin{tabular}{|l|c|c|c|c|}
\hline Sample type & $\begin{array}{c}\text { Measurement } \\
\text { parameters }\end{array}$ & $\begin{array}{c}\text { Analyzed } \\
\text { elements }\end{array}$ & $\begin{array}{c}\text { Measuremen } \\
\text { trange } \\
{[\mathrm{mg} / \mathrm{kg}]^{*}}\end{array}$ & Bibl. \\
\hline \multicolumn{3}{|c|}{ Wavelength dispersive X-Ray fluorescence WD-XRF } \\
\hline
\end{tabular}

\begin{tabular}{|l|c|c|c|}
\hline Liquid, solid or & $30-50 \mathrm{kV}, 30-70$ & $\mathrm{~S}$ & $0.001-2.5$
\end{tabular}

\begin{tabular}{l|c|c} 
semi-solid & $\mathrm{mA}$ & [\% mas.]
\end{tabular}

petroleum products crystal: Ge, PET, graphite

film: polyester or

polypropylene IS: $\mathrm{Zr}$

\begin{tabular}{|c|c|c|c|c|}
\hline & & & & \\
\hline Petroleum products & $\begin{array}{c}\text { Crystal: LiF or } \\
\text { other } \\
\text { IS: } \mathrm{Mn}\end{array}$ & $\begin{array}{l}\mathrm{Ni} \\
\mathrm{V}\end{array}$ & $\begin{array}{c}5-100 \\
5-1000\end{array}$ & [17] \\
\hline Ethanol & $>30 \mathrm{kV},>50 \mathrm{~mA}$ & $\mathrm{~S}$ & $7-20$ & [18] \\
\hline
\end{tabular}

\begin{tabular}{|l|l}
\hline Ethanol & $>30 \mathrm{kV},>50 \mathrm{~mA}$ \\
crystal: Ge, PET,
\end{tabular} graphite

\begin{tabular}{l|l} 
& Film: polyester \\
\hline Liquid fuels (cont. & $>30 \mathrm{kV},>50 \mathrm{~mA}$ \\
\hline
\end{tabular}

$\leq 3.7 \%$ mas. of crystal: Ge, PET,

oxygen) graphite

\begin{tabular}{|l|c|c|c|c|} 
& Film: polyester & & & \\
\hline Petrol & $50 \mathrm{kV}, 25-45 \mathrm{~mA}$, & $\mathrm{Pb}$ & $2.6-1320$ & {$[20]$} \\
\hline
\end{tabular}

\begin{tabular}{|l|c|c|c|} 
& $\begin{array}{c}\text { crystal: LiF } \\
\text { IS: Bi (met. A) }\end{array}$ & $\begin{array}{r}2.6-1 \\
{[\mathrm{mg} / 1}\end{array}$ \\
\hline \multicolumn{4}{|c|}{ Energy dispersive X-Ray fluorescence ED-XRF } \\
\hline Petrol (cont. & - & $\mathrm{S}$ & $8-50$
\end{tabular}

$\leq 3.7 \%$ mas. of

oxygen)

Petrol (cont.

$\leq 10 \%$ vol. of

ethanol)

Diesel cont.

$\leq 10 \%$ vol. of

FAME)

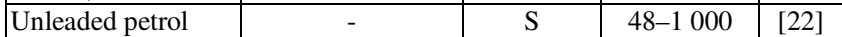

\begin{tabular}{|l|c|c|c|c|}
\hline \multicolumn{5}{|c|}{ Atomic absorption spectrometry AAS } \\
\hline FAME & $\begin{array}{c}\text { Dilution 25x with } \\
\text { xylene or } \\
\text { cyclohexane }\end{array}$ & $\mathrm{Na}$ & $\geq 1$ & {$[23]$} \\
\hline FAME & $\begin{array}{c}\text { Dilution 25x with } \\
\text { xylene or } \\
\text { cyclohexane }\end{array}$ & $\mathrm{K}$ & $\geq 0.5$ & {$[24]$} \\
\hline \multicolumn{4}{|c|}{ Ultra violet fluorescence UV-F } \\
\hline
\end{tabular}

\begin{tabular}{|l|l|l|l|l|}
\hline Petrol (cont. & Burning in 1000- & $\mathrm{S}$ & $3-500$ & [25] \\
\hline
\end{tabular}

$\leq 3.7 \%$ mas. of

oxygen)

Petrol (cont.

$\leq 10 \%$ vol.

of ethanol)

Diesel (cont.

$\leq 10 \%$ vol.

of FAME)

Biodiesel, fuels,

light hydrocarbons,

engine oils

\section{$1100^{\circ} \mathrm{C}$}

Measurement of

$\mathrm{SO}_{2}$, direct

measurement or dilution with

toluene or

isooctane

Burning in 1075

Measurement of

$\mathrm{SO}_{2}$, direct

measurement or

dilution with

xylenes or

isooctane

* - other units indicated below, IS - Internal Standard

\subsection{Sample preparation for ICP-OES/AES measurements}

One of most important stages, in each analytical procedure is sample preparation. Improper sample preparation may lead to enrichment or impoverishment of analitu, for example due to contamination. That is why the sample preparation procedure should be as simple as 
possible to minimalize possibility of error. Sampled fuel should be homogenous and usually requires placing in water bath [6], homogenization by intensive mixing [7-10, $14,21]$, heating up to $60-100^{\circ} \mathrm{C}$ and intensive shaking [4, 11] or by mechanical homogenization [14].

After homogenization, in case of ICP-OES or ICP-AES, usually sample is diluted with pure solvent with viscosity and boiling point similar to the sample. Alternatively direct measurements of undiluted samples are also possible. However it is important to bear in mind that both of this approaches are improper if insoluble particles are to be taken into account in elemental analysis, and may lead to underestimation of results [4, 14]. It is of high importance that standards solutions and samples have very similar viscosity as this is the critical parameter influencing spraying efficiency in spray chamber of spectrometer. That is why both, samples and standards solutions, should be prepared with the use of the same solvent. Additionally, in order to increase accuracy of the results internal standards (IS) are used and their role is to correct matrix effects and slight differences between viscosities of the samples and standards solutions. Internal standards are used in form of metalorganic compounds of usually: Sc, Y or Co, which are not present in the sample. In case of highly volatile samples as ethanol or petrol measurements may be performed on undiluted samples however, it may result in unstable plasma work and cooled spray chamber may be required.

\section{Experimental}

Elements concentration was measured by inductively coupled plasma optical emission spectrometer Perkin Elmer Optima 8300 with horizontal plasma and binary, radial and axial, observation system.

Due to low concentration of elements, below $1 \mathrm{mg} / \mathrm{kg}$, samples after homogenization were analyzed undiluted. International standards recommends minimum 10x dilution what significantly deteriorate determination limits which in result makes accurate determination of trace elements difficult. Such approach is relatively easy for petrol and diesel containing up to $10 \%$ vol. of FAME (B10), however in case of pure FAME its viscosity is too high and sample dilution was required. For dilution of high viscosity samples V-solv (VHG Labs, Manchester, USA) solvent was used (declared concentration of elements below $0.25 \mu \mathrm{g} / \mathrm{g}$ ).

Before measurements optimization of spectrometer parameters was done for each analyzed element, in order to achieve limit of determination as low as possible, signal to background ratio as high as possible, repeatable measurements and stable plasma work. Selected working conditions are presented in Table 3. For each analyzed element plasma gas flowrate, auxiliary gas flowrate, nebulizer gas flowrate, plasma power and observation direction were optimized. For most of analyzed elements, except $\mathrm{Al}, \mathrm{B}, \mathrm{Cr}, \mathrm{K}$ and $\mathrm{Na}, 2$ or 3 analytical lines were chosen and applied. In case of potassium and phosphorous binary plasma observation, radial and axial, was applied. Obtained limits of quantification (LOQ) were: $0.1 \mathrm{mg} / \mathrm{kg}$ for $\mathrm{Al}, \mathrm{Ba}, \mathrm{Ca}, \mathrm{Cu}, \mathrm{Fe}, \mathrm{Mg}, \mathrm{Mn}, \mathrm{Pb}, \mathrm{Si}, \mathrm{Ti}$, $\mathrm{V}$ and $\mathrm{Zn} ; 0.3 \mathrm{mg} / \mathrm{kg}$ for $\mathrm{Cr}$ and $0.5 \mathrm{mg} / \mathrm{kg}$ for $\mathrm{B}, \mathrm{K}, \mathrm{Mo}, \mathrm{Na}$, $\mathrm{Ni}, \mathrm{P}$ and $\mathrm{Sn}$.

Four point calibration curves were prepared for each analyzed element and were based on multielemental standard solutions obtained by dilution of basic standard solution of elemnts in metalorganic form and concentration of 100 mg/kg each (WM-22-10x-100, AccuStandard, New Heaven, USA). Correlation coefficient for most elements was above 0,9995, except: $\mathrm{Na}\left(\mathrm{r}^{2}=0.9991\right)$ and $\mathrm{P}\left(\mathrm{r}^{2}=0.9979\right)$. Correctness of developed method was checked by testing of measurement repeatability (relative variation coefficient for $1.0 \mathrm{mg} / \mathrm{kg}$ concentration level was from 2.1 to $11.4 \%$ depending on measured element), recovery by standard addition method (90.2-114.4\%, except B: $80.4 \%$ ) and correctness of calibration curves preparation (98.7-108.4\%).

Table 3. ICP-OES Optima 8300 work parameters

\begin{tabular}{|c|c|}
\hline Parameter & Working conditions \\
\hline RF generator power & $1500 \mathrm{~W}$ \\
\hline Plasma gas flowrate & $18 \mathrm{~L} / \mathrm{min}$ \\
\hline Auxiliary gas flowrate & $1.0 \mathrm{~L} / \mathrm{min}$ \\
\hline Nebulizer gas flowrate & $0.35-0.45 \mathrm{~L} / \mathrm{min}$ \\
\hline Nebulizer & Parallel (V-groove type) \\
\hline Spray chamber & Glass cyclonic Baffled-type \\
\hline Central torch pipe & Quartz, i.d. $0.8 \mathrm{~mm}$ \\
\hline
\end{tabular}

\section{Results and discussion}

The aim of conducted research was quality check of fuels from Polish market. Over 370 samples of fuels: diesel without FAME (B0), diesel with up to $7 \%$ vol. FAME (B7), diesel with up to $10 \%$ vol. FAME (B10) and FAME (B100) were tested within four years between 2013 and 2017. Within these samples there were 96 samples of B0, 207 samples of B7, 66 samples of B10 and 10 samples of B100.

Average elements contents in tested fuels are presented in Figs 1-3. Comparison of measured elements concentrations including minimum and maximum values is presented in Table 4, and these are the typical elements contents in tested fuels.

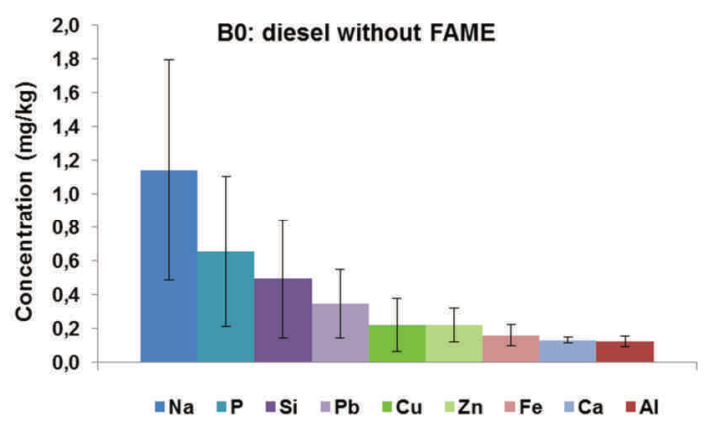

Fig. 1. Concentration of main elements in B0 diesel fuels

Elements most frequently present in B0, B7 and B10 fuel samples were: $\mathrm{Al}, \mathrm{Ca}, \mathrm{Cu}, \mathrm{Na}, \mathrm{P}, \mathrm{Pb}, \mathrm{Si}$ and $\mathrm{Zn}$. Within these elements sodium was predominant taking into account both: its concentration in fuels and its presence frequency. Average sodium content in B0, B7 and B10 was ca. $1,0 \mathrm{mg} / \mathrm{kg}$, and it was present in $90 \%$ of tested B0 samples and $78 \%$ of B7 and B10 fuel samples. In case of pure FAME, B100 samples sodium content was significantly higher $(6.3 \pm 1.3 \mathrm{mg} / \mathrm{kg})$, however only 10 samples of B100 were tested. In case of silicon, average concentration in B0 samples was $0.5 \mathrm{mg} / \mathrm{kg}$ with maximum of $1.6 \mathrm{mg} / \mathrm{kg}$ (presence in $81 \%$ of B0 samples), in B7 average concentration was $0.3 \mathrm{mg} / \mathrm{kg}$ with maximum at $1.0 \mathrm{mg} / \mathrm{kg}$ (presence in $57 \%$ of samples) and in case 
of B10 average content of silicon was $0.2 \mathrm{mg} / \mathrm{kg}$ with maximum of $0.6 \mathrm{mg} / \mathrm{kg}$ (presence in $68 \%$ analyzed samples). It was noticed that average silicon content was decreasing with increasing of FAME content in diesel fuel.

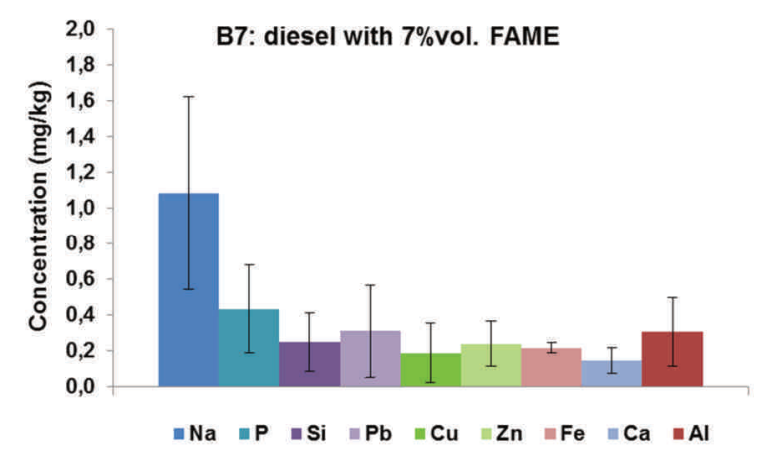

Fig. 2. Concentration of main elements in B7 diesel fuels

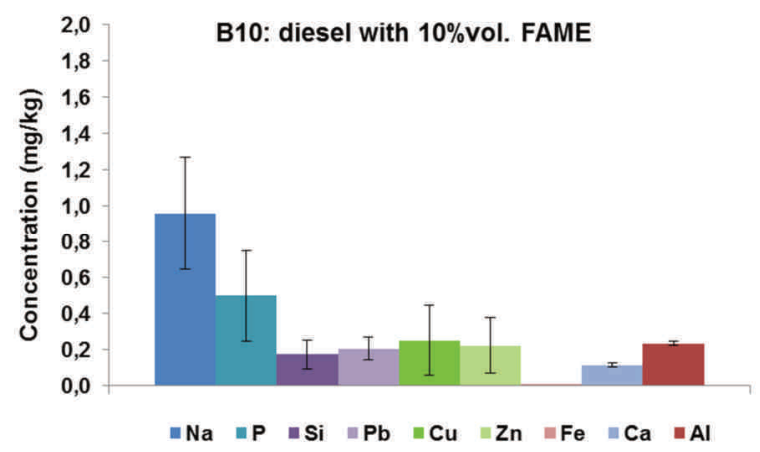

Fig. 3. Concentration of main elements in B10 diesel fuels

Zinc was present in tested fuels samples at average level of $0.22 \pm 0.13 \mathrm{mg} / \mathrm{kg}$ and no relation to biocomponent content in fuel was noticed. In case of pure FAME average concentration of this element was $0.76 \mathrm{mg} / \mathrm{kg}$.

The highest phosphorous content was noticed in FAME samples (average of $2.8 \mathrm{mg} / \mathrm{kg}$ ) while in fuels samples it was on average level of $0.5 \mathrm{mg} / \mathrm{kg}$, in the range of minimum 0.1 and maximum $1.7 \mathrm{mg} / \mathrm{kg}$. Similar dispersion of results was observed in case of silicon, average value of 0.3 $\mathrm{mg} / \mathrm{kg}$ with dispersion of results from 0.1 to $1.6 \mathrm{mg} / \mathrm{kg}$ and in case of lead, average value of $0.3 \mathrm{mg} / \mathrm{kg}$ with dispersion from 0.1 to $1.4 \mathrm{mg} / \mathrm{kg}$. Phosphorous presence was noticed in case of $31 \%$ of B 0 samples, $51 \%$ of B 7 samples and $62 \%$ of B10 samples, while lead was present in $44 \%$ of B0 samples, $41 \%$ of B7 and $32 \%$ of B10 samples.

There was no B, Ba, Cr, K, Mn, Sn, Ti, and V presence noticed in case of any of tested samples. Other elements than these mentioned above were present in relatively small number of samples, like magnesium, which presence was noticed only in 4 from 90 tested B0 samples. Moreover, its concentration was $0.1 \mathrm{mg} / \mathrm{kg}$ which was also the limit of quantification. Iron and nickel were present in some individual cases ie. Fe was present in 12 samples of B0 and only in 4 samples of B7, while $\mathrm{Ni}$ in 5 samples of B7 and 2 samples of B10. There were no iron presence noticed in any of B10 and B100 samples as well as no Ni presence in B0 and B100 samples. Molybdenum concentration in most of the samples was below limit of quantification $(0.5 \mathrm{mg} / \mathrm{kg})$ and was estimated in the range of $0.15-0.30 \mathrm{mg} / \mathrm{kg}$. Molybdenum concentration was higher than LOQ only in three cases of B7 fuels.

Table 4. Elements content in fuels and biofuels $\mathrm{mg} / \mathrm{kg}$

\begin{tabular}{|c|c|c|c|c|}
\hline \multirow{2}{*}{ Element } & $\begin{array}{c}\mathrm{B} 0 \\
\mathrm{n}=96)\end{array}$ & $\begin{array}{c}\mathrm{B} 7 \\
(\mathrm{n}=207)\end{array}$ & $\begin{array}{c}\text { B10 } \\
(\mathrm{n}=66)\end{array}$ & $\begin{array}{c}\mathrm{B} 100 \\
(\mathrm{n}=10) \\
{[\mathrm{mg} / \mathrm{kg}]}\end{array}$ \\
\cline { 2 - 4 } & \multicolumn{3}{|c|}{$\min -\mathrm{max}[\mathrm{mg} / \mathrm{kg}]$} \\
\hline $\mathrm{Zn}$ & $0.10-0.47$ & $0.10-0.64$ & $0.10-0.58$ & $0.76 \pm 0.27$ \\
\hline $\mathrm{Al}$ & $0.10-0.20$ & $0.10-0.58$ & 0.24 & $<0.1$ \\
\hline $\mathrm{B}$ & $<0.1$ & $<0.1$ & $<0.1$ & $<0.1$ \\
\hline $\mathrm{Ba}$ & $<0.5$ & $<0.5$ & $<0.5$ & $<0.5$ \\
\hline $\mathrm{Ca}$ & $0.11-0.15$ & $0.10-0.43$ & $0.10-0.13$ & $0.17 \pm 0.09$ \\
\hline $\mathrm{Cr}$ & $<0.3$ & $<0.3$ & $<0.3$ & $<0.3$ \\
\hline $\mathrm{Cu}$ & $0.10-0.81$ & $0.10-0.72$ & $0.10-0.74$ & $0.13 \pm 0.04$ \\
\hline $\mathrm{Fe}$ & $0.11-0.32$ & $0.19-0.25$ & $<0.1$ & $<0.1$ \\
\hline $\mathrm{K}$ & $<0.5$ & $<0.5$ & $<0.5$ & $<0.5$ \\
\hline $\mathrm{Mg}$ & 0.10 & $<0.1$ & $<0.1$ & $<0.1$ \\
\hline $\mathrm{Mn}$ & $<0.1$ & $<0.1$ & $<0.1$ & $<0.1$ \\
\hline $\mathrm{Mo}$ & $<0.5$ & $<0.5-0.75$ & $<0.5$ & $<0.5$ \\
\hline $\mathrm{Na}$ & $0.42-2.8$ & $0.16-2.4$ & $0.29-1.7$ & $6.3 \pm 1.3$ \\
\hline $\mathrm{Ni}$ & $<0.5$ & $<0.5-0.59$ & 0.56 & $<0.5$ \\
\hline $\mathrm{P}$ & $0.10-1.7$ & $0.11-1.5$ & $0.14-1.3$ & $2.8 \pm 1.0$ \\
\hline $\mathrm{Pb}$ & $0.13-0.94$ & $0.10-1.4$ & $0.13-0.33$ & $<0.1$ \\
\hline $\mathrm{Si}$ & $0.12-1.6$ & $0.10-1.0$ & $0.11-0.57$ & $<0.1$ \\
\hline $\mathrm{Sn}$ & $<0.5$ & $<0.5$ & $<0.5$ & $<0.5$ \\
\hline $\mathrm{Ti}$ & $<0.1$ & $<0.1$ & $<0.1$ & $<0.1$ \\
\hline $\mathrm{V}$ & $<0.1$ & $<0.1$ & $<0.1$ & $<0.1$ \\
\hline & & & & \\
\hline
\end{tabular}

The lowest results dispersion was observed in case of calcium. This element was present in $8 \%$ of total samples number and its average concentration was $0.13 \pm 0.03$ $\mathrm{mg} / \mathrm{kg}$. Copper, which was present in $26 \%$ of total samples, results dispersion was significantly higher with average concentration for this element $0.22 \pm 0.16 \mathrm{mg} / \mathrm{kg}$.

\section{Conclusions}

Negative effect of some elements presence, especially $\mathrm{Zn}, \mathrm{Na}$ and $\mathrm{Si}$, on engine performance is well known [5]. In some cases relatively small increase in some elements concentration may lead to significant engine performance drop. This is particularly true in case of soap formatting elements like $\mathrm{Na}$, which responsibility for injector cooking is of great importance. The effects of other elements than mentioned above on engine performance is not that well known, mainly due to their trace level presence in most of diesel fuels. However, while dynamic development of combustion engines is taken into account with the accompanying development of alternative fuels production processes, it is possible that some of the elements which presence is not of that great importance, like the ones mentioned earlier, may become more important in the future.

Inductively coupled plasma emission spectrometry is a well-known and mature technique allowing measurements of broad range elements in the limits usually do not achievable for other spectrometry techniques, like X-Ray fluorescence or atomic absorption spectrometry. Different possibilities relating to sample preparation and control of versatile measurement parameters by ICP-OES techniques allows reaching very low LOQ values what is necessary for monitoring of trace elements. Despite the fact that, in case of diesel fuels, only sulfur and manganese content is limited by the standards there is need to other elements monitoring, especially in case of engine testing or vehicle testing activities as their presence may have significant effect on engine 
performance. The effect of fuel contamination with trace elements in regular car usage will have presumably less dy- namic nature and the engine performance drop will be less noticeable.

\section{Nomenclature}

AAS atomic absorption spectrometry

ED-XRF energy disppersive X-Ray fluorescence

IS internal standard

ICP-OES inductively coupled plasma optical emission spectrommetry

ICP-AES inductively plasma coupled atomic emission spectrometry

\section{Bibliography}

[1] PN-EN 590:2013 Automotive fuels - diesel - requirements and test methods.

[2] PN-EN 228:2013 Automotive fuels - unleaded petrol requirements and test methods.

[3] PN-EN 14214:2012 Fatty acid methyl esters (FAME) for use in diesel engines and heating applications - requirements and test methods.

[4] ASTM D7111-16 Standard test method for determination of trace elements in middle distillate fuels by inductively coupled plasma atomic emission spectrometry (ICP-AES).

[5] BARKER, J., COOK, S., RICHARDS, P. Sodium contamination of diesel fuel, its interaction with fuel additives and the resultant effects on filter plugging and injector fouling, SAE International Journal of Fuels and Lubrication. 2013, 6(3), 826-838.

[6] PN-EN 15837: 2011 Ethanol as a blending component for petrol. Determination of phosphorous, copper and sulfur content. Direct method by inductively coupled plasma optical emission spectrometry (ICP OES).

[7] PN-EN 14538:2008 Fat and oil derivatives. Fatty acid methyl ester (FAME). Determination of $\mathrm{Ca}, \mathrm{K}, \mathrm{Mg}$ and $\mathrm{Na}$ content by optical emission spectral analysis with inductively coupled plasma (ICP OES).

[8] PN-EN 16136:2015-03 Automotive fuels. Determination of manganese and iron content in unleaded petrol. Inductively coupled plasma optical emission spectrometry (ICP OES) method.

[9] PN-EN 16294:2013-05 Petroleum products and fat and oil derivatives. Determination of phosphorus content in fatty acid methyl esters (FAME). Optical emission spectral analysis with inductively coupled plasma (ICP OES).

[10] PN-EN 16476:2014-07 Liquid petroleum products. Determination of sodium, potassium, calcium, phosphorus, copper and zinc contents in diesel fuel. Method via inductively coupled plasma optical emission spectrometry (ICP OES).

[11] PN-EN 15944:2011 Liquid petroleum products. Determination of nickel and vanadium content. Inductively coupled plasma optical emission spectrometry method (ICP OES).

[12] PN-EN 14107:2004 Fat and oil derivatives. Fatty acid methyl esters (FAME). Determination of phosphorous content by inductively coupled plasma (ICP) emission spectrometry.

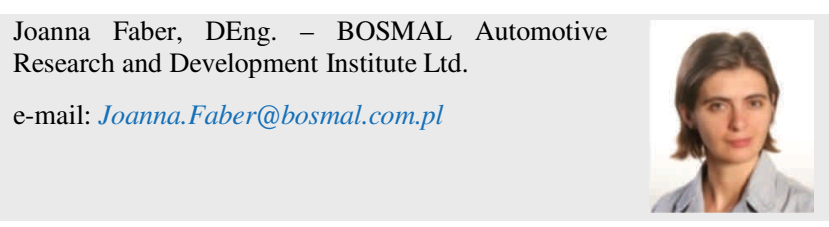

$\begin{array}{ll}\text { LOQ } & \text { limit of quantification } \\ \text { LOD } & \text { limit of determiantion } \\ \text { UV-F } & \text { ultra-violet fluorescence } \\ \text { WD-XRF } & \text { wavelenght disppersive X-Ray fluorescence }\end{array}$

[13] PN-EN 16576:2014-12 Automotive fuels. Determination of manganese and iron content in diesel. Inductively coupled plasma optical emission spectrometry (ICP OES) method.

[14] PN-V-04030:2000 Oznaczanie zawartości pierwiastków w paliwach płynnych i produktach podobnych metodą emisyjnej spektrometrii atomowej $\mathrm{z}$ plazmą indukcyjnie wzbudzoną (ICP AES).

[15] ASTM D 5708-12 Standard test methods for determination of nickel, vanadium, and iron in crude oils and residual fuels by inductively coupled plasma (ICP) atomic emission spectrometry.

[16] PN-EN ISO 14596:2009 Petroleum products. Determination of sulfur content. Wavelength-dispersive X-ray fluorescence spectrometry.

[17] PN-EN ISO 14597:2005 Petroleum products. Determination of vanadium and nickel content. Wavelength-dispersive Xray fluorescence spectrometry.

[18] PN-EN 15485:2009 Ethanol as a blending component for petrol. Determination of sulfur content. Wavelength dispersive X-ray fluorescence spectrometric method.

[19] PN-EN ISO 20884:2012 Petroleum products. Determination of sulfur content of automotive fuels. Wavelength-dispersive $\mathrm{X}$-ray fluorescence spectrometry.

[20] ASTM D 5059-14: Standard test methods for lead in gasoline by X-ray spectroscopy.

[21] PN-EN ISO 13032:2012 Petroleum products. Determination of low concentration of sulfur in automotive fuels. Energydispersive X-ray fluorescence spectrometric method.

[22] ASTM D 6445-99: Standard test method for sulfur in gasoline by energy-dispersive $\mathrm{X}$-ray fluorescence spectrometry.

[23] PN-EN 14108:2004 Fat and oil derivatives. Fatty acid methyl esters (FAME). Determination of sodium content by atomic absorption spectrometry.

[24] PN-EN 14109:2004 Fat and oil derivatives. Fatty acid methyl esters (FAME). Determination of potassium content by atomic absorption spectrometry.

[25] PN-EN ISO 20846:2012 Petroleum products. Determination of sulfur content of automotive fuels. Ultraviolet fluorescence method.

[26] ASTM D 5453-16e: Standard test method for determination of total sulfur in light hydrocarbons, spark ignition engine fuel, diesel engine fuel, and engine oil by ultraviolet fluorescence.

Krzysztof Brodzik, DEng. - BOSMAL Automotive Research and Development Institute Ltd.

e-mail: Krzysztof.Brodzik@bosmal.com.pl 